\title{
Karakteristik Limbah Cair Pasar Kedondong, Kelurahan Karang Asam Ilir, Kecamatan Sungai Kunjang, Kota Samarinda
}

\author{
Kemala Hadidjah \\ Pengelolaan Lingkungan, Politeknik Pertanian Negeri Samarinda, Kota Samarinda, 75131 \\ kemala.hadidjah@politanisamarinda.ac.id
}

\begin{abstract}
Abstrak-Limbah cair yang dihasilkan dari kegiatan Pasar Kedondong dapat menimbulkan efek buruk untuk lingkungan sekitar. Penelitian ini bertujuan untuk mengetahui karakteristik limbah cair yang dihasilkan, dan dapat memberikan suatu informasi tentang dampak limbah cair yang telah dihasilkan dari Pasar Kedondong, serta membandingkan limbah cair yang dihasilkan oleh Pasar Kedondong dengan baku mutu air limbah domestik menurut Kep.No P.68/Menlhk-Setjen/2016. Metode pada penelitian ini menggunakan metode survei. Pengambilan sampel menggunakan botol gelap dan grab sample. Pengambilan sampel air limbah cair dilakukan dengan mengacu pada SNI 6989.59:2008 Bagian 59 tentang metode pengambilan contoh air limbah. Pengambilan sampel dilakukan sebanyak 3 kali ulangan dalam satu titik dengan ukuran $250 \mathrm{~mL}$ yang ditempatkan pada botol gelap dan didinginkan dalam coolbox Hasil penelitian ini menunjukkan warna sampel terlihat coklat, memiliki bau yang menyengat dan tidak sedap. Sedangkan nilai rata-rata parameter air limbah cair Pasar Kedondong menunjukkan rata-rata $\mathrm{pH}$ di lapangan 6,94 dengan suhu $28{ }^{\circ} \mathrm{C}$ dan $\mathrm{pH}$ di laboratorium menunjukkan rata-rata pHnya 7,00. Analisis pH limbah cair Pasar Kedondong masih memenuhi baku mutu lingkungan domestik menurut Kep.No P.68/Menlhk-Setjen/2016. Limbah cair Pasar Kedondong yang dianalisis di Laboratorium menunjukkan hasil rata-rata parameter TSSnya 246 mg/L, yang artinya melebihi baku mutu lingkungan air limbah domestik menurut Kep.No P.68/Menlhk-
\end{abstract} Setjen/2016.

Kata Kunci-Karakteristik limbah cair, Pasar Kedondong, pH, TSS, suhu

\section{PENDAhuluan}

Pasar Kedonodong merupakan salah satu pasar tradisional yang terletak di kawasan pemukiman padat penduduk dan terletak di Jalan Ulin, Kelurahan Karang Asam Ilir, Kecamatan Sungai Kunjang, tepatnya di pinggiran anak Sungai Mahakam. Limbah cair buangan dari Pasar Kedondong langsung dibuang begitu saja ke badan perairan tanpa adanya pengolahan khusus. Pasar Kedondong terbagi menjadi bagian basah dan kering. Bagian basah yaitu tempat ikan, daging, dan ayam. Sedangkan bagian kering yaitu tempat sayur, baju, dan perlengkapan rumah tangga.
Limbah cair dari Pasar Kedondong langsung dibuang ke anak Sungai Mahakam. Limbah cair yang melewati sungai terus membawa zat-zat yang berbahaya sehingga sungai tersebut menjadi tercemar. Padahal sungai sangat bermanfaat bagi masyarakat yang tinggal di sekitar sungai tersebut. Apalagi masih banyak masyarakat yang memanfaatkan sungai sebagai tempat mencuci motor, pakaian, bahkan mandi.

Karakteristik limbah cair dari Pasar Kedondong masih belum diketahui secara pasti. Oleh karena itu, penelitian ini bertujuan untuk mengetahui karakteristik limbah cair dari parameter $\mathrm{pH}$, TSS, suhu, warna dan bau.

\section{METODOLOGI}

1. Lokasi dan Waktu Penelitian

Penelitian dilakukan di kawasan Pasar Kedondong, Kelurahan Karang Asam Ilir, Kecamatan Sungai Kunjang, Kota Samarinda, Provinsi Kalimantan Timur. Pengambilan data berlangsung selama satu bulan, yakni bulan Juni sampai Juli 2019. Lokasi penelitian terdiri dari satu titik, yaitu pada saluran sebelum masuk ke perairan penerima air limbah.

\section{Alat dan Bahan}

Alat dan bahan yang digunakan dalam penelitian ini adalah botol sampel (jerigen plastik), gelas, kamera digital, tisu, alat tulis, $\mathrm{pH}$ meter, termometer, cooling box.

\section{Prosedur Penelitian}

Pengambilan sampel dilakukan sebanyak 3 kali pengulangan pada satu titik dengan menggunakan cara grab sample. Pengambilan sampel dilakukan pada saluran sebelum masuk ke perairan penerima air limbah. Sampel yang telah diambil selanjutnya akan dianalisis di Laboratorium Tanah dan Air Politeknik Pertanian Negeri Samarinda. Pengambilan sampel limbah cair dilakukan dengan mengacu pada SNI 6989.59:2008 Bagian 59 tentang metode pengambilan contoh air limbah.

\section{Analisis Data}

Analisis data dilakukan di dua tempat, yaitu di Laboratorium Tanah dan Air Politeknik Pertanian Negeri Samarinda Samarinda untuk parameter TSS, dan langsung di lapangan untuk parameter $\mathrm{pH}$, suhu, warna, dan bau. 


\section{HASIL DAN PEMBAHASAN}

Hasil yang dicapai dalam pengamatan langsung di lapangan dan di Laboratorium Tanah dan Air Politeknik Pertanian Negeri Samarinda terhadap limbah cair di Pasar Kedondong ditampilkan pada tabel berikut.

Tabel 1. Hasil Analisis pH, TSS, Suhu, Warna, dan Bau pada Limbah Cair Pasar Kedondong

\begin{tabular}{|l|l|l|l|}
\hline Parameter & $\begin{array}{l}\text { Hasil } \\
\text { Pengukuran }\end{array}$ & $\begin{array}{l}\text { Standar } \\
\text { baku mutu }\end{array}$ & Metode Analisis \\
\hline $\mathrm{pH}$ & 6,94 & $6-9$ & $\begin{array}{l}\text { SNI 06-6989.11- } \\
2004\end{array}$ \\
\hline TSS & $246 \mathrm{mg} / \mathrm{L}$ & $30 \mathrm{mg} / \mathrm{L}$ & $\begin{array}{l}\text { SNI 06-6989.3- } \\
2004\end{array}$ \\
\hline Suhu & $28^{\circ} \mathrm{C}$ & & Pemuaian \\
\hline Warna & $\begin{array}{l}\text { Coklat } \\
\text { kehitaman }\end{array}$ & & Visual \\
\hline Bau & Bau busuk & & Penciuman \\
\hline
\end{tabular}

Kota Samarinda merupakan ibukota Propinsi Kalimantan Timur, dimana perkembangan kotanya sangat dipengaruhi oleh berbagai aktivitas di segala sektor, salah satunya adalah sektor jasa perdagangan (pasar). Pasar sebagai tempat perdagangan berpotensi menimbulkan berbagai macam limbah, diantaranya adalah limbah cair. Limbah cair dari Pasar Kedondong berasal dari aktivitas pencucian lantai serta barangbarang dagangan yang langsung dibuang menuju sungai tanpa melalui proses pengolahan terlebih dahulu.

Hasil pengamatan secara visual diperoleh fakta bahwa warna sampel air terlihat coklat kehitaman dan memiliki bau busuk yang menyengat. Hal ini dapat disebabkan karena beberapa faktor yaitu tingkat pembuangan limbah yang berasal dari bermacammacam aktivitas, seperti kegiatan pencucian sayuran, meja bekas ikan, dan lantai kios toko.

Selain mengamati warna dan bau, $\mathrm{pH}$ dan suhu air sampel juga dilakukan pengukuran secara langsung di lapangan. Nilai rata-rata $\mathrm{pH}$ yang didapatkan adalah 6,94 dengan suhu $28^{\circ} \mathrm{C}$. Pengukuran nilai $\mathrm{pH}$ juga dilakukan di laboratorium dengan nilai 7. Berdasarkan nilai baku mutu lingkungan domestik menurut Kep.No P.68/Menlhk-Setjen/2016, didapatkan bahwa kandungan $\mathrm{pH}$ dalam air sampel limbah cair Pasar Kedondong masih di ambang batas; bisa juga diartikan bahwa masih aman.

Hasil laboratorium menyatakan bahwa nilai kandungan TSS sebesar $246 \mathrm{mg} / \mathrm{L}$. Jika dibandingkan dengan standar baku mutu lingkungan Kep.No P.68/Menlhk-Setjen/2016, maka nilai kandungan TSS tersebut telah melebihi batas ambang. Hal ini dapat disebabkan karena banyaknya pembuangan limbah yang berasal dari bermacam-macam aktivitas yang meliputi kegiatan pencucian meja bekas membersihkan ikan, sayuran, dan lantai kios toko. Dari aktivitas tersebut dapat menghasilkan padatan atau kotoran, sehingga dapat menimbulkan kekeruhan air yang terdiri dari lumpur, pasir, serta sisa-sisa potongan badan ikan yang terbawa ke dalam badan air.

\section{KESIMPULAN}

Berdasarkan hasil analisis, secara visual, warna dan bau air sampel limbah cair Pasar Kedondong terlihat keruh coklat kehitaman dan memiliki bau yang busuk. Kandungan nilai $\mathrm{pH}$ yang didapatkan sebesar 6,9 dan masih dalam batas ambang baku mutu lingkungan menurut Kep.No P.68/Menlhk-Setjen/2016 Pengambilan sampel limbah cair pada saluran sebelum masuk ke badan perairan penerima limbah dan telah dilakukan pengukuran kadar TSS didapatkan nilai ratarata sebesar $246 \mathrm{mg} / \mathrm{L}$ dan telah melebihi batas ambang baku mutu lingkungan menurut Kep.No P.68/MenlhkSetjen/2016. Hal ini dikarenakan banyaknya buangan limbah yang berasal dari berbagai macam aktivitas pencucian, seperti pencucian sayuran, meja bekas membersihkan ikan, dan lantai kios toko. Dimana segala aktivitas tersebut dapat menghasilkan padatan atau kotoran yang ikut terbuang ke saluran pembuangan.

\section{DAFTAR PUSTAKA}

Azmi., Saniman. Dan Ishak. 2016. Sistem Perhitungan pH Air Pada Tambak Ikan Berbasis Mikrokontroller. Jurnal Saintikom Vol 15, No. 2 ISSN: 1978-6603

Habibi. dan R. Marwan 2018. Pengaruh Limbah Terhadap Lingkungan Dan Penyakit YangTimbul Serta Penanggulangannya. Tegal: Bagian Penerbitan Fakultas Teknik Universitas Pancasakti. ISSN: 2579-6429.

Kencanawati. 2016. Sistem Pengelolaan Air Limbah. Bukit Jimbaran: Bagian Penerbit Fakultas Teknik Universitas Udayana.

Lestari. 2009. Pendugaan Konsentrasi Total Suspended Solid (TSS) Dan Transparansi Perairan Teluk Jakarta Dengan Citra Satelit Landsat. Bogor: Bagian Penerbitan Fakultas Perikanan Dan Ilmu Kelautan Institut Pertanian Bogor.

Mukarromah. 2016. Analisis Sifat Fisis Dalam Studi Kualitas Air Di Mata Air Sumber Asem Dusun Kalijeruk, Desa Siwuran, Kecamatan Garung, Kabupaten Wonosobo. Semarang: Bagian Penerbitan Fakultas Matematika Dan Ilmu Pengetahuan Alam Universitas Negeri Semarang.

Pontorondo. 2016. Perubahan Perilaku Berbelanja Dari Pasar Tradisional ke Pasar Modern di Kota Manado Dipandang Dari Aspek Sosiologi. Jurnal Ilmiah AlSyir'ah Vol. 14 No.2

Yudo. 2017. Kebijakan Dan Strategi Pengelolaan Air Limbah Domestik Di Indonesia. Vol. 10, No.2:58-75

Zulkifli. 2017. Pengolahan Limbah Cair Industri. Makassar: Bagian Penerbitan Fakultas Teknologi Industri Universitas Muslim Indonesia 